\title{
DESIGN DATABASE FOR APPLICATION INTRODUCTION OF BOGOR BATIK MOTIF WEB-BASED
}

\author{
Adriana Sari Aryani ${ }^{\left.a^{*}\right)}$, Irma Anggraeni ${ }^{a)}$ \\ ${ }^{a)}$ Universitas Pakuan, Bogor, Indonesia \\ ${ }^{*}$ Corresponding Author: adriana.aryani@gmail.com
}

Article history: received 09 July 2019; revised 17 July 2019; accepted 25 August 2019

\begin{abstract}
Abstrak. Bogor batik motifs are inspired by the legacy of the kingdom of Pakuan, historical objects, phenomena, and culture. One of the famous motifs is the Kujang Kijang motif. In addition to deer motifs, Batik Bogor also has other unique motifs such as the pilsau cleaver motif and drizzling rain. Bogor Batik motifs applied in batik scratches are mostly symbols of the City of Bogor itself. The deer head motif is a mirror of the Bogor Palace, the lotus motif becomes a symbol of the Bogor Botanical Gardens, the cleaver blade as a symbol of the city of Bogor and the drizzle motif as the designation of the city of Bogor. Database Design is the process of determining the content and data settings needed to support various system designs. The purpose of Database Design is: to fulfill information that contains specific user needs and their applications. facilitate understanding of information structures, support processing needs and multiple object appearance (response time, processing time, and storage space). In the web-based Bogor batik motif introduction application using the DBS SQL Server. The advantages of Microsoft SQL Server one of which can work very well on all windows operating systems.
\end{abstract}

Keywords: Bogor batik motif; database design; batik pattern recognition

\section{INTRODUCTION}

The times are moving very fast, both in terms of technology and in terms of science. As the development of increasingly sophisticated human brain technology, many foreign cultures that enter our country will poison the morals and mentality of future generations [1]. Utilization of Technology can be applied in all fields of life, one of which is in the fields of education and culture. Batik is a culture that has long been developed and is known by the people of Indonesia [2]. Various kinds of batik can be found in Indonesia, including: Bogor batik, Cirebon batik, Ciamis batik, Garut batik, and Cianjur batik. The tradition of making batik was originally a hereditary tradition, so that the batikan motifs can be recognized and become patterns or motifs from certain families or regions. Each batik region has a variety of different motifs that become the uniqueness of each [4].

Bogor Batik motifs applied in batik strokes are mostly symbols of the city of Bogor itself. The deer head motif is a mirror of the Bogor Palace, the lotus motif is a symbol of the Bogor Botanical Garden, the kujang knife as the symbol of the city of Bogor and the drizzle motif as the city of Bogor. Botanical garden motifs display a variety of contents from the botanical garden such as lotus, carrion flower, uncal or deer and large trees in the Dutch heritage garden.

The Batik Kujang Kijang motif contains two icons of the city of Bogor, namely Kujang and Kijang. Kujang is a traditional Sundanese weapon, while deer is an animal in the Bogor Palace. The introduction of batik motifs can use a web-based application where later the wider community can access the Batik web and get to know Bogor motifs. One example of the use of the web in the field of culture is: the application of the introduction of various batik motifs typical of web-based Bogor.

\section{RESEARCH METHODS}

This study uses the SDLC Method. System development method SDLC (System Development Life Cycle) method or often referred to as the waterfall approach (waterfall). The waterfall method was first introduced by Windows W. Royce in 1970. Waterfall is a simple classic model with a linear system flow [5]. The output of each stage is an input for the next stage. SDLC is a process to understand how an information system can support business needs by designing a system, building the system and conveying it to users. The strengths of SDLC are: the process becomes organized, the schedule becomes more uncertain, the process is easy to understand and clear, easy to manage the project, the conditions are clear requirements. The SDLC method can be seen in Figure 1.

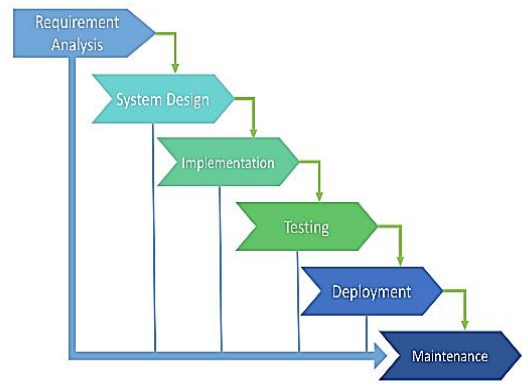

Figure 1. SDLC Method 
At the system analysis stage, determining the goals and who the program users are (audience identification), types of applications (presentations, interactive, etc.), application objectives (information, entertainment, training, etc.), and general specifications [6]. This stage is determined that this application has the aim to introduce a variety of typical batik motifs in Bogor in the form of a picture that will be output later in the form of a description, history, or philosophy about batik motifs that have been photographed before. In the system analysis phase will be carried out an analysis of the data and create a design for structuring data in the form of images that are processed using image processing. Image analysis basically consists of three stages, namely feature extraction, segmentation, and classification. In extracting the feature the edge edge detection method is used. Edge detection is a step to cover information in an image. Edge characterizes the boundary of objects and therefore edges are useful for the process of segmentation and identification of objects in the image. At the system design stage, database design and user interface design will be carried out. Database Design is the process of determining the content and data settings needed to support various system designs [7]. The purpose of Database Design is: to fulfill information that contains specific user needs and their applications. The design of the User Interface is a communication mechanism between the user (user) and the system [8]. The user interface (user interface) can receive information from the user (user) and provide information to the user (user) to help direct the search flow of the problem until a solution is found.

\section{RESULTS AND DISCUSSION}

Context Diagram application introduction to Bogor batik motifs web-based explains that it can be accessed by two types of users, namely: User, and Admin. A database management system (DBMS) is a collection of interrelated data and a set of programs that access that data. Data sets are usually referred to as databases that contain relevant information. The main purpose of a DBMS is to provide a way to store and access information that is appropriate and efficient. In the web-based Bogor batik motif introduction application using the DBS SQL Server. The advantages of Microsoft SQL Server one of which can work very well on all windows operating systems [9]. This is of course due to the fact that Microsoft SQL Servers is also a DBMS software created and developed by Microsoft itself, therefore Microsoft SQL Server is very good and also suitable when used and also applied to the Windows operating system. Microsoft SQL Servers also has another advantage that is quite good, which can help make the creation of data clustering. Clustering this data is one of the things that can help facilitate the work of database or database management, so that the data that will be processed using Microsoft SQL Servers software will be easier to implement, because it can be divided into several clusters. SQLServer's appearance for the database-based application for Bogor-based batik batik motifs can be seen in Figure 2.

\begin{tabular}{|c|c|c|c|}
\hline & TOP-F82ACCSI...Weh & Quizzes $+\not X$ & -F82ACCS \\
\hline & Column Name & Data Type & Allow Nulls \\
\hline 8 & Quizld & int & $\square$ \\
\hline & Question & nvarchar(MAX) & $\nabla$ \\
\hline & Option1 & nvarchar(MAX) & $\nabla$ \\
\hline & Option1Score & int & $\square$ \\
\hline & Option2 & nvarchar(MAX) & $\nabla$ \\
\hline & Option2Score & int & $\square$ \\
\hline & Option3 & nvarchar(MAX) & $\nabla$ \\
\hline & Option3Score & int & $\square$ \\
\hline & Option4 & nvarchar(MAX) & $\nabla$ \\
\hline & Option4Score & int & $\square$ \\
\hline & & & $\square$ \\
\hline
\end{tabular}

Figure 2. SQLServer Database Base View

In the BatikWeb database there are seven tables that will be accessed in the web-based Bogor batik motif introduction application. The seven tables are: Images Table, Product Table, User Table, Quiz Table, Quiz Responses Table, ImageDescriptor Table, EFMigrationsHistory Table. Table Design Images can be seen in Figure 3. Quiz Table Design can be seen in Figure 4. User Table Design can be seen in Figure 5.

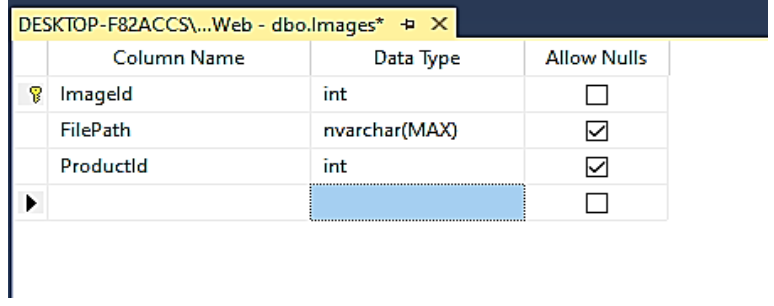

Figure 3. Table Design Images

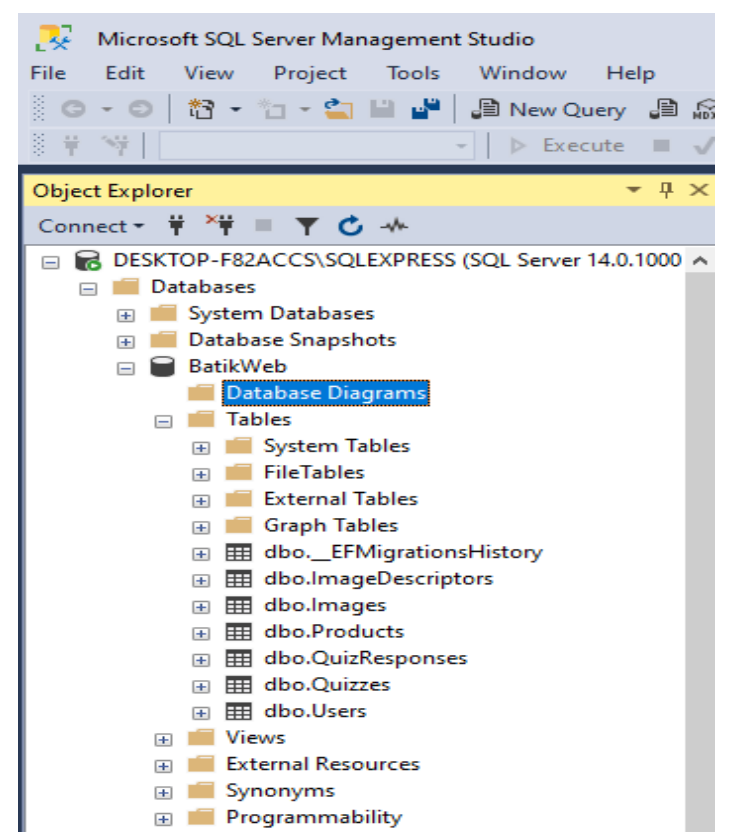

Figure 4. Table Design Quiz 


\begin{tabular}{|c|c|c|c|}
\hline \multicolumn{3}{|c|}{ DESKTOP-F82ACCSI...Web - dbo.Quizzes } & DESKTOP-F82ACCS $\backslash . . . \mathrm{ikWeb}$ \\
\hline & Column Name & Data Type & Allow Nulls \\
\hline \multirow[t]{7}{*}{ 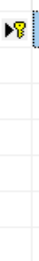 } & Userld & int & $\square$ \\
\hline & FullName & nvarchar(MAX) & $\square$ \\
\hline & Username & nvarchar(MAX) & $\square$ \\
\hline & HashedPassword & nvarchar(MAX) & $\square$ \\
\hline & Email & nvarchar(MAX) & $\square$ \\
\hline & [Level] & int & $\square$ \\
\hline & & & $\square$ \\
\hline
\end{tabular}

Figure 5. Table Design User

\section{CONCLUSION}

Various kinds of batik can be found in Indonesia, including: Bogor batik, Cirebon batik, Ciamis batik, Garut batik, and Cianjur batik. The tradition of making batik was originally a hereditary tradition, so that the batikan motifs can be recognized and become patterns or motifs from certain families or regions. Each batik region has a variety of different motifs that become the uniqueness of each. The introduction of batik motifs can use a web-based application where later the wider community can access the Batik web and get to know Bogor motifs.

In the web-based Bogor batik motif introduction application using the DBS SQL Server. The advantages of Microsoft SQL Server one of which can work very well on all windows operating systems. In the database for the introduction of Bogor batik motifs, there are seven tables that will be accessed in the web-based Bogor batik motif introduction application. The seven tables are: Images Table, Product Table, User Table, Quiz Table, Quiz Responses Table, ImageDescriptor Table, EFMigrationsHistory Table.

\section{REFERENSI}

[1] Gardjito, Murdijati. 2015. Batik Indonesia Mahakarya Penuh Pesona. Yogyakarta. Kaki Langit.

[2] Suryana,Yan Yan. 2013. Batik Digitalisasi Kreatif Motif Dalam Gaya Desain Dunia. Bandung. Penerbit ITB

[3] Atik,S.Ken. 2013. Batik Jawa Barat. Bandung. Penerbit : Yayasan Batik Jawa Barat

[4] Jayanti, Ni Ketut. 2018. Teori Basis Data. Penerbit : Andi Offset

[5] Agung, Gregorius. Step by Step MS SQL Server. Penerbit : Jubilee Enterprise

[6] Firmansyah, Yoki. 2018 Penerapan Metode SDLC Waterfall Dalam Pembuatan Sistem Informasi Akademik Berbasis Web Studi Kasus Pondok Pesantren Al-Habi Sholeh Kabupaten Kubu Raya, Kalimantan Barat. Jurnal Teknologi dan Manajemen Informatika Vol. 04 No.1 2018.

[7] Fathansyah. 2012. Basis Data. Informatika, Bandung

[8] Sidik, Betha. 2014. Pemrograman Web dengan PHP (Revisi Kedua). Informatika, Bandung
[9] Sutanta, Edhy. 2011. Basis Data dalam Tinjauan Konseptual. Penerbit : Andi Offset. 